$\Phi=$ 줄

\title{
Characterization of the geological and geotechnical properties of soil using the surface wave approach
}

\author{
Oloye, O. E. ${ }^{1 *}$, Adepelumi, A. A. ${ }^{1}$

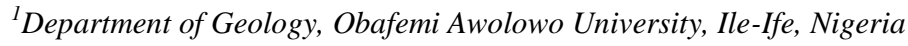 \\ *Corresponding author E-mail:oluwatobioloye@gmail.com
}

\begin{abstract}
As part of the efforts to examine the elastic and engineering properties of the subsurface sequence at a proposed new power plant site in Edo State, a geophysical survey involving Multichannel Analysis of Surface Waves (MASW) was carried out. The MASW was adopted to determine the vertical and lateral variations in velocity beneath each seismic line. The MASW was carried out on two seismic lines each trending NE-SW. A geophone interval of $3 \mathrm{~m}$ was used, and the length of the seismic lines ranged from $60-90 \mathrm{~m}$. The ES-3000 seismograph was used for the surface wave data acquisition and the Shear-Wave velocity structures of the area were obtained through the inversion of the acquired surface wave data. The one dimensional (1D) S-Wave velocity profiles along the lines were diagnostic of generally low velocity lithologies that suggest sand, clayey sand and sandy clay formations with relatively varying thicknesses. The subsurface layers delineated had shear-wave velocity values in the range of 63-400 m/s. They were classified using the NEHRP Seismic Site Classification, and all of them were in the range of stiff soil to soft clay soil. The bulk moduli $(\mathrm{k})$ for these soils were in the range of 3.22-3.98 GPa. This depicts relatively low strength of the subsurface materials. The shear moduli $(\mu)$ values range from 7.15-7.43 MPa, which is indicative of low to moderate strength. The information provided in this study will aid the structural engineer or architect in foundation design of the proposed power plant. From the results of this study, it is concluded that although the subsurface layers are of relatively low strength, with the right intervention of the civil engineer, a suitable foundation can be designed for the gas plant.
\end{abstract}

Keywords:Coastal Plain Sands;MASW;Soil Stability;Velocity Variations.

\section{Introduction}

Civil Engineering structures are founded on or within the earth. One of the priority considerations in the design of the foundation of such structures, therefore, is the pre-construction investigation of the proposed site in order to ascertain the competence of the host earth material. The pre-construction investigation may involve direct mechanical boring, pitting, and trenching for subsurface sequence delineation, groundwater table mapping, soil sampling and geotechnical laboratory analysis. It may also involve non-invasive geophysical investigations.

The pre-construction investigation provides information on the subsurface lithologies and their thicknesses identifies the competent bedrock and determines depths to its upper interface, available geological structures, bedrock relief or configuration and the degree of competence of the foundation bedrock (Aina et al., 1996; Adewumi and Olorunfemi, 2005; and Idornigie et al., 2006) which is the purpose of this investigation.

In geotechnique, subsoil competence is evaluated through series of tests, which include compaction, triaxial, and consolidation tests. In geophysical prospecting, the Compressional (P) and Shear (S) wave velocities in earth materials can be used to evaluate subsoil competence through the determination of the bulk modulus (Sjqgren et al., 1979 and Dutta, 1984) as well as its shear modulus. A compact subsoil is characterized by reduced porosity and moisture content with the consequent increase in Shear wave and Compressional wave velocities.
Recent work has shown that surface wave observables possess sensitivity to density as well as shear wave velocity (Lin et al., 2012). Furthermore, other various wave types have found usage in geotechnical and geophysical mapping; for example direct waves map out the smooth velocity variations in cross well seismic tomography; wide angle refracted waves play a crucial role in full waveform inversion (Hole et al., 2005), and surface waves provide unmatched sensitivity to near-surface shear wave velocity structure. Surveys based on surface waves provide a low-cost, noninvasive means of probing the shallow subsurface using either active sources (Xia et al., 1999) or in passive mode using microtremors (Aki, 1957, 1965; Louie, 2001; Okada, 2003).

This investigation provides information on the subsurface sequence; the elastic and engineering properties estimated using empirical relations at the proposed gas power plant site. The following objectives were utilized: (a) acquire Rayleigh wave data using vertical component seismometers, (b) generate the 1-D SWave velocity structures of the subsurface, (c) estimate the bulk moduli of the subsurface sequence and thereby determine the strength of the sequence, (d) classify the subsurface sequence using the generated S-Wave velocity structures and estimated bulk moduli, proffer the necessary measures to be put in place for proper foundation design of the gas power plant.

\section{Location, Geology and Hydrogeology}

The study area (Figure 1) is located in Edo State, Nigeria. It lies within Latitudes $5^{\circ} 59^{\prime} 49^{\prime \prime}$ and $5^{\circ} 60^{\prime} 00^{\prime \prime}$ North of the Equator 
and Longitudes $5^{0} 53$ ' 53.5' and $5^{0} 53^{\prime} 54^{\prime \prime}$ East of the Greenwich Meridian.

The area is underlain by the Coastal Plain Sands or the Benin Formation (Figure 2). The sediments of the Coastal Plain, deposited during the Late Tertiary - Early Quaternary period (Jones and Hockey, 1964), consist of unconsolidated, coarse to medium-fine grained sands and clayey shale in places (Okosun, 1988). The sands are generally moderately sorted and poorly cemented. The Benin Formation is overlain by lateritic overburden or recent alluvial deposits. The Coastal Plain Sands to constitute the major shallow hydrogeologic units in the area. The lateritic earth overlying the sands, as well as the underlying impervious clay/shale member of the Agbada Formation, constitute protective configuration for the aquifer units. Also, the high annual rainfall and other favourable climatic and geologic factors guarantee adequate groundwater recharge in the area (Omosuyi et al., 2008).

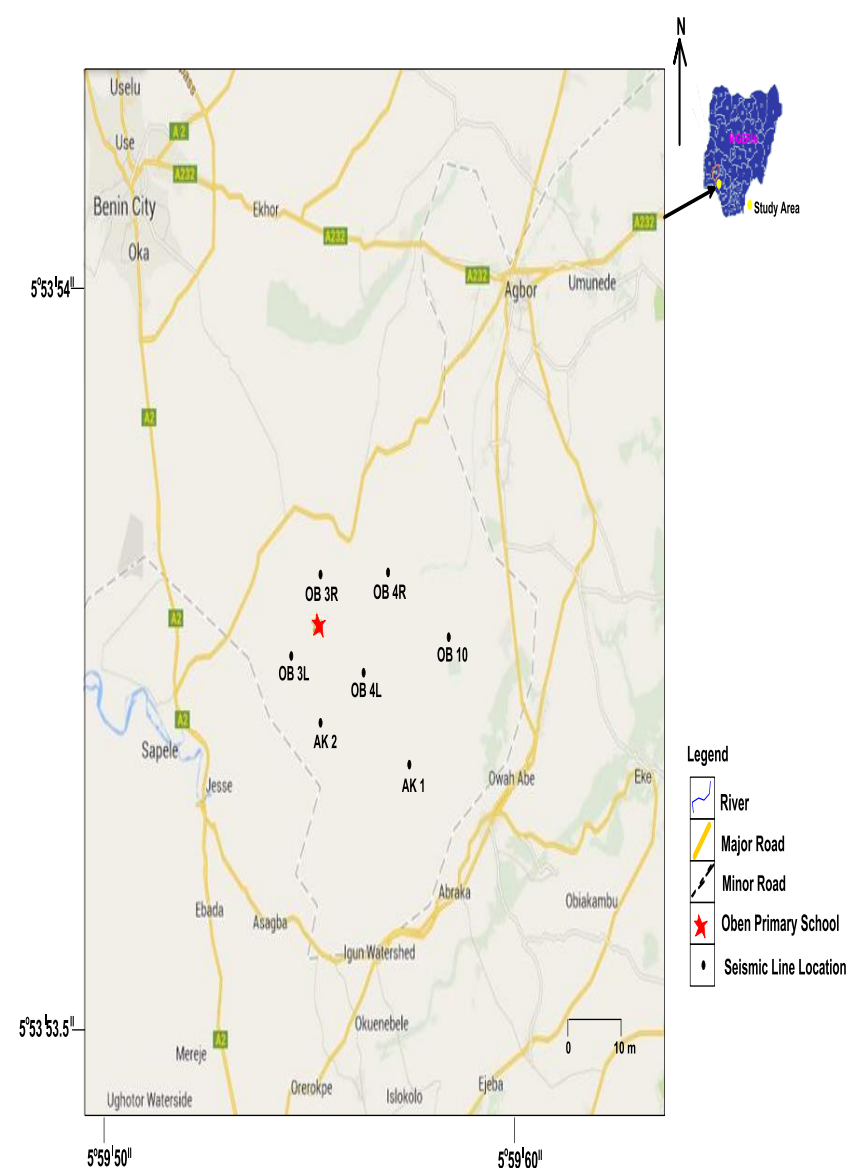

Fig. 1: Location and Data Acquisition Map of the Study Area (Modified from Google Maps).

\section{Methodology}

Two seismic lines were established at the site each trending in the NE-SW direction. The Surface Wave method was applied in this survey and utilized the Multichannel Analysis of Surface Waves technique. The MASW survey was adopted to determine the lateral and vertical ground velocity variations beneath each seismic line. The ES-3000 seismograph was used for the surface wave data acquisition along the two studied segments.

A geophone interval of $3 \mathrm{~m}$ was used, and the length of the seismic lines ranged from $60-90 \mathrm{~m}$. The acquired surface-wave data were inverted using SeisImager SOFTWARE, and the interpretation results were presented as velocity profiles.

\section{Results and Discussion}

The S-Wave velocity models derived for the two wells are shown in Figures 3-6. A distinct gradual velocity variation with depth is observed in the shear wave velocity models.

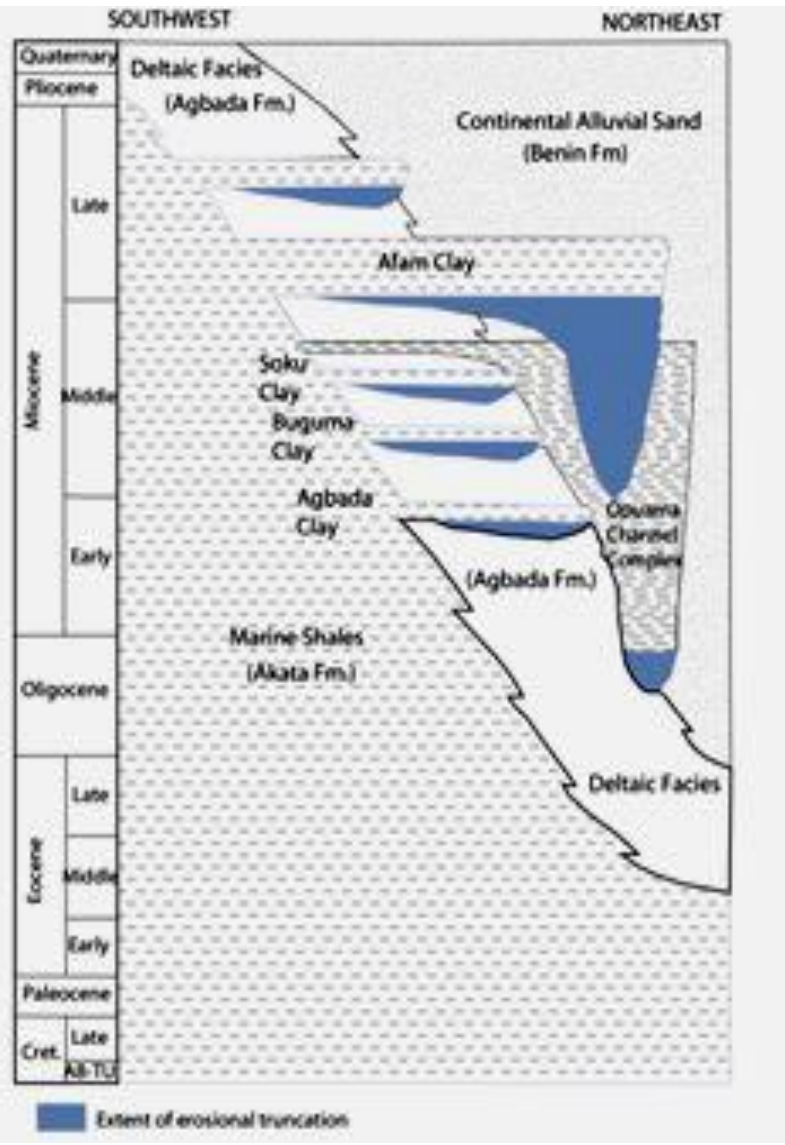

Fig. 2: Stratigraphic Column of the Three Formations of the Niger Delta (Modified From Shannon and Naylor (1989)). 


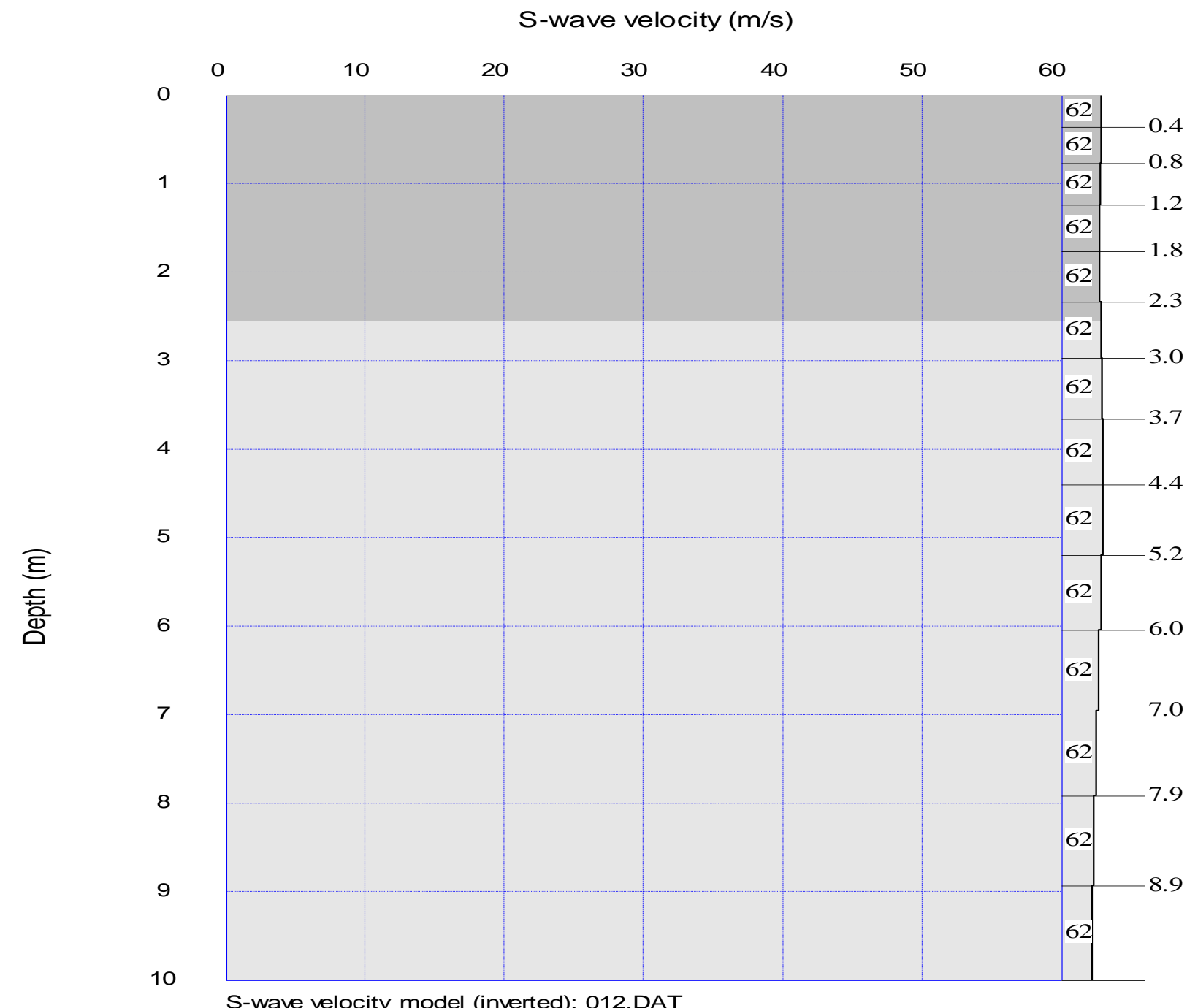

S-wave velocity model (inverted): 012.DAT

Average Vs $30 \mathrm{~m}=63.0 \mathrm{~m} / \mathrm{sec}$

Fig. 3: S-Wave Velocity Curve for Well 1

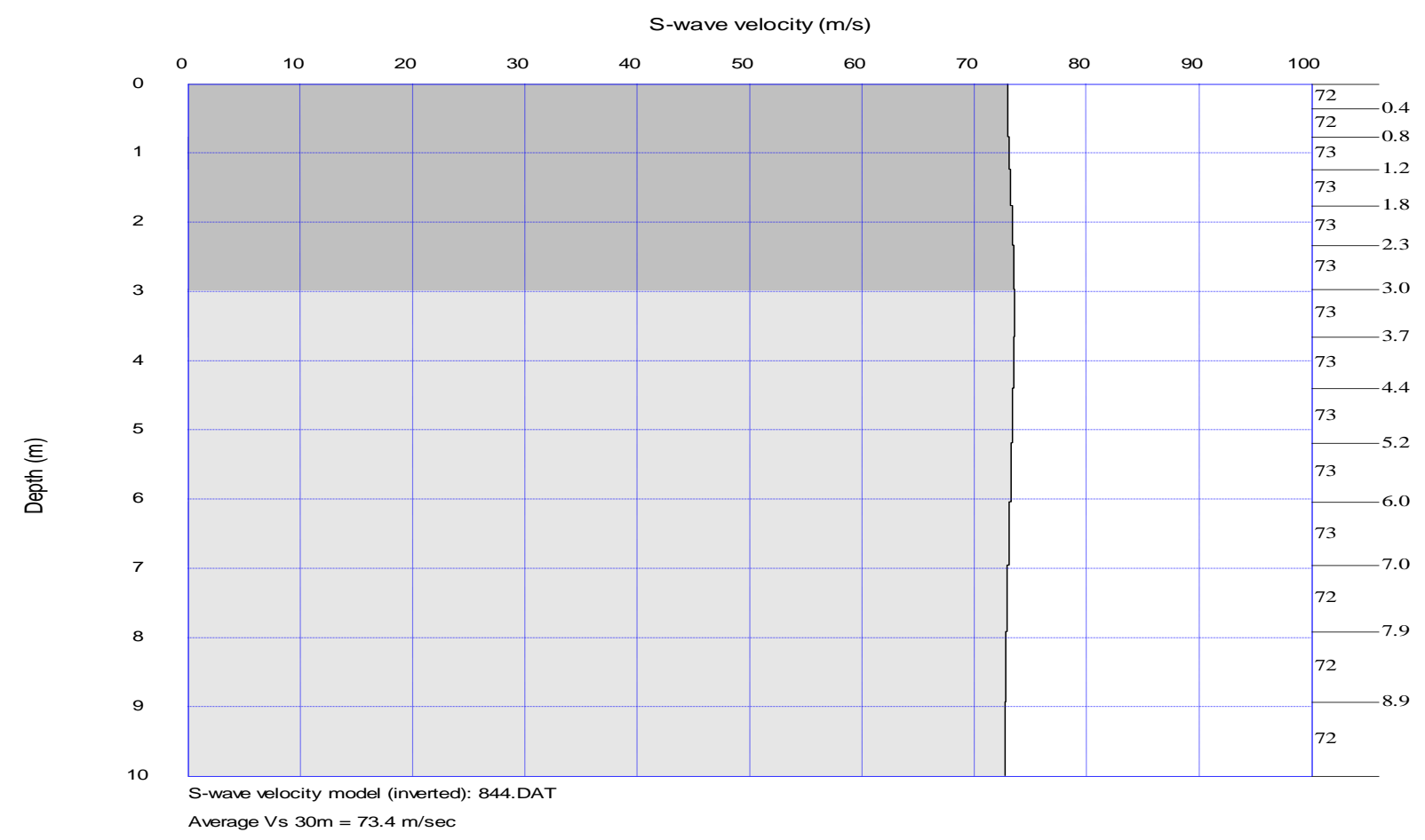

Fig. 4: S-Wave Velocity Curve for Well 2 


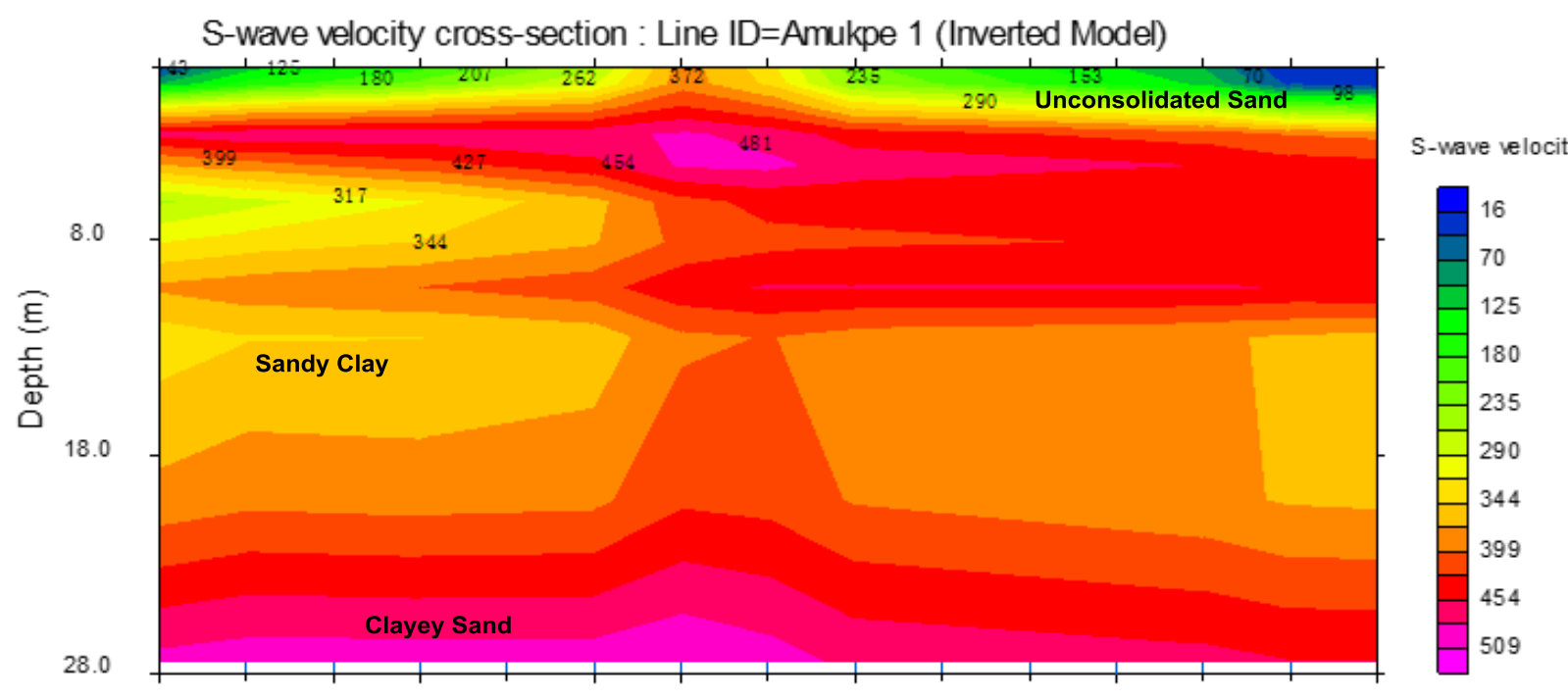

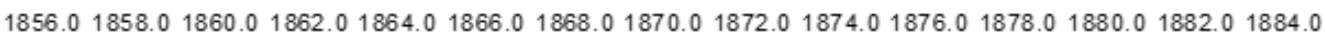

$(\mathrm{m} / \mathrm{sec})$

Distance $(\mathrm{m})$

Fig. 5: Inverted S-Wave Velocity Model for Well 1.

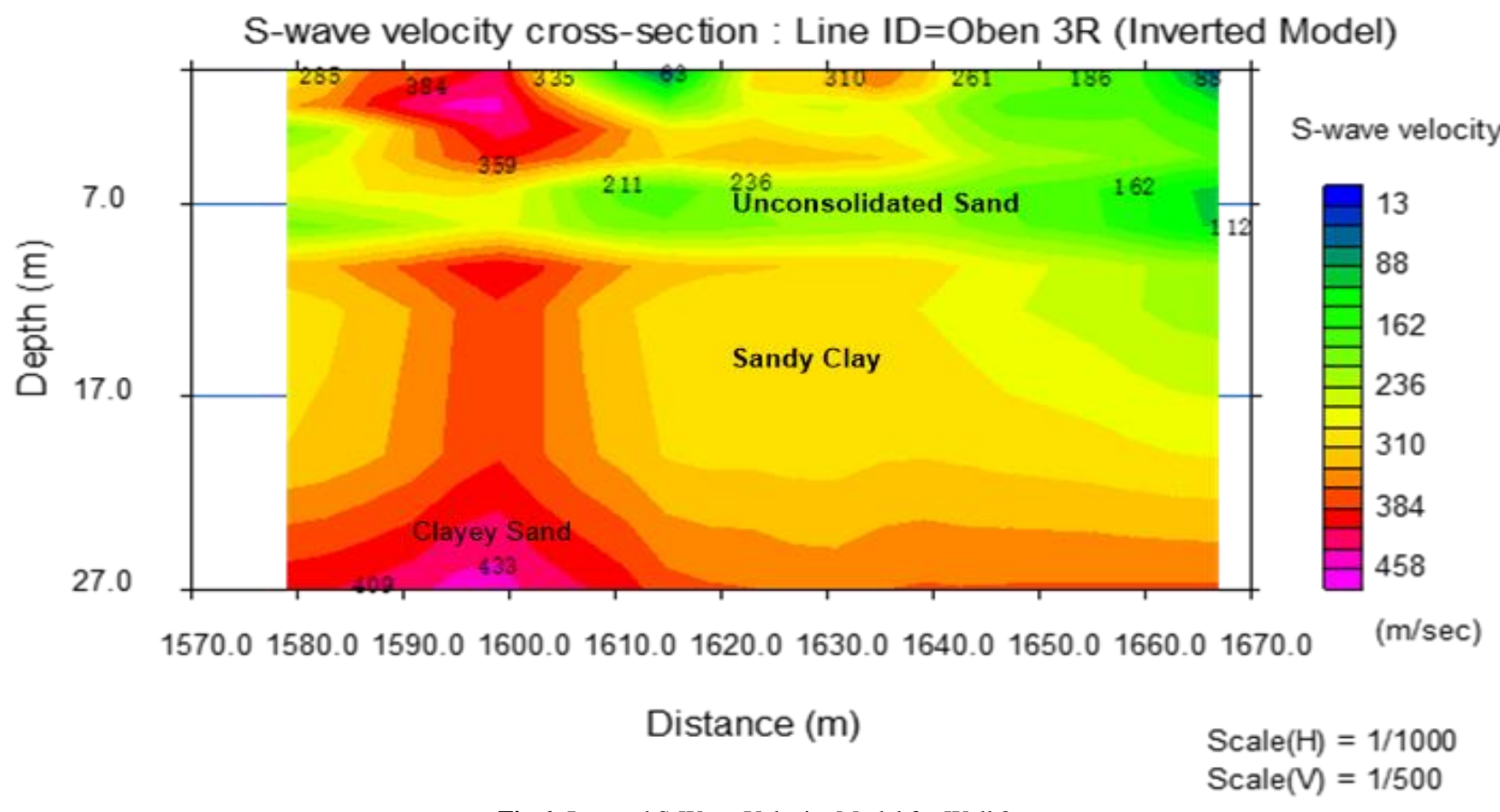

Fig.6: Inverted S-Wave Velocity Model for Well 2.

For the upper $10 \mathrm{~m}$ of the wells studied; this is the area of concern for engineering construction.

The average shear-wave velocity in Well 1 is $63 \mathrm{~m} / \mathrm{s}$ and $73.4 \mathrm{~m} / \mathrm{s}$ in Well 2.

These 2D S-Wave velocity models suggest that the upper $10 \mathrm{~m}$ of the wells are characterized by unconsolidated sand, sandy clay and clayey sand.

The derived elastic and physical properties of the formations encountered in the two wells investigated in this study are shown in Tables 1-2. The computation of the $\mathrm{V}_{\mathrm{s}}, \mathrm{V}_{\mathrm{p}}, \rho, \mathrm{V}_{\mathrm{s}}{ }^{2}, \mathrm{~V}_{\mathrm{p}}{ }^{2}, 4 / 3 \mathrm{~V}_{\mathrm{s}}{ }^{2}, \mu$, $\left[\mathrm{V}_{\mathrm{P}}^{2}-\frac{4}{3} \mathrm{~V}_{\mathrm{S}}^{2}\right]$ and bulk moduli $\mathrm{K}$ for the wells were carried out in order to understand the elastic, physical, insitu and engineering properties of the formations encountered in the wells studied.

The NEHRP seismic site classification (Table 3) which is based on shear-wave velocity can be used to classify the soils.
Using the site classification technique in Table 3, it is observed that Well 1 falls within site class E, Well 2 falls within site class E. The soil types in class D and E are generally classified as stiff soil to soft clay soil.

Generally, it is evident that the subsurface formations in the area investigated are characterized with low to moderate bulk moduli $(\mathrm{K})$ values and shear moduli $(\mu)$ values in the range of 3.2-3.9 GPa and 7.15-7.43 MPa respectively. These values suggest low shear strength for the subsurface formations for the depth range investigated.

Before construction of the Gas Plant, it is appropriate to subject the soils to ground improvement such as chemical injection, vibratory compaction and vacuum preloading methods in order to stabilize the soils. 
The soil types found in the wells were classified using the NEHRP seismic site classification that is based on shear-wave velocities only (Table 3).

Table 1:Table of Elastic and Physical Properties for Well 1.

\begin{tabular}{|c|c|c|c|c|c|c|c|c|c|c|}
\hline Layer & $\mathrm{V}_{\mathrm{s}}(\mathrm{m} / \mathrm{s})$ & $\mathrm{V}_{\mathrm{p}}(\mathrm{m} / \mathrm{s})$ & $\rho\left(\mathrm{g} / \mathrm{cm}^{3}\right)$ & $\rho\left(\mathrm{kg} / \mathrm{m}^{3}\right)$ & $\mu(\mathrm{MPa})$ & $\mathrm{V}_{\mathrm{p}}^{2}\left(\mathrm{~m}^{2} / \mathrm{s}^{2}\right)$ & $\mathrm{V}_{\mathrm{s}}^{2}\left(\mathrm{~m}^{2} / \mathrm{s}^{2}\right)$ & $\begin{array}{l}\left\{4 / 3\left(\mathrm{~V}_{\mathrm{s}}^{2}\right)\right\} \\
\left(\mathrm{m}^{2} / \mathrm{s}^{2}\right)\end{array}$ & $\begin{array}{l}\left\{\left(\mathrm{V}_{\mathrm{p}}^{2}\right)-4 / 3\left(\mathrm{~V}_{\mathrm{s}}^{2}\right)\right\} \\
\left(\mathrm{m}^{2} / \mathrm{s}^{2}\right)\end{array}$ & $\mathrm{K}(\mathrm{GPa})$ \\
\hline 1 & 65.191 & 1362.188 & 1.74203 & 1742.03 & 7.4034 & 1855554.813 & 4249.896 & 5666.528 & 1849888.285 & 3.2225 \\
\hline 2 & 65.077 & 1362.236 & 1.74203 & 1742.03 & 7.3776 & 1855686.554 & 4235.069 & 5646.758 & 1850039.796 & 3.2228 \\
\hline 3 & 65.191 & 1362.362 & 1.74203 & 1742.03 & 7.4034 & 1856030.839 & 4249.896 & 5666.528 & 1850364.311 & 3.2233 \\
\hline 4 & 65.303 & 1362.487 & 1.74203 & 1742.03 & 7.4289 & 1856369.826 & 4264.523 & 5686.030 & 1850683.796 & 3.2239 \\
\hline 5 & 65.348 & 1362.537 & 1.74203 & 1742.03 & 7.4392 & 1856507.591 & 4270.473 & 5693.965 & 1850813.627 & 3.2241 \\
\hline 6 & 65.309 & 1362.494 & 1.74203 & 1742.03 & 7.4304 & 1856389.480 & 4265.371 & 5687.162 & 1850702.318 & 3.2239 \\
\hline 7 & 65.198 & 1362.370 & 1.74203 & 1742.03 & 7.4050 & 1856052.395 & 4250.826 & 5667.768 & 1850384.627 & 3.2234 \\
\hline 8 & 65.036 & 1362.191 & 1.74203 & 1742.03 & 7.3684 & 1855564.143 & 4229.802 & 5639.736 & 1849924.407 & 3.2226 \\
\hline 9 & 64.848 & 1361.982 & 1.74203 & 1742.03 & 7.3257 & 1854993.696 & 4205.295 & 5607.060 & 1849386.636 & 3.2216 \\
\hline 10 & 64.652 & 1361.764 & 1.74203 & 1742.03 & 7.2815 & 1854401.244 & 4179.921 & 5573.228 & 1848828.017 & 3.2207 \\
\hline 11 & 64.465 & 1361.557 & 1.74203 & 1742.03 & 7.2395 & 1853837.380 & 4155.837 & 5541.116 & 1848296.264 & 3.2197 \\
\hline 12 & 64.301 & 1361.375 & 1.74203 & 1742.03 & 7.2028 & 1853342.366 & 4134.746 & 5512.994 & 1847829.372 & 3.2189 \\
\hline 13 & 64.171 & 1361.230 & 1.74203 & 1742.03 & 7.1736 & 1852947.835 & 4117.975 & 5490.633 & 1847457.202 & 3.2183 \\
\hline 14 & 64.082 & 1361.132 & 1.74203 & 1742.03 & 7.1537 & 1852679.063 & 4106.566 & 5475.422 & 1847203.642 & 3.2178 \\
\hline 15 & 65.484 & 1362.688 & 1.74203 & 1742.03 & 7.4702 & 1856918.304 & 4288.235 & 5717.647 & 1851200.657 & 3.2248 \\
\hline
\end{tabular}

Table 2:Table of Elastic and Physical Properties for Well 2.

\begin{tabular}{llllllllll}
\hline Layer & $\mathrm{V}_{\mathrm{s}}(\mathrm{m} / \mathrm{s})$ & $\mathrm{V}_{\mathrm{p}}(\mathrm{m} / \mathrm{s})$ & $\rho\left(\mathrm{g} / \mathrm{cm}^{3}\right)$ & $\rho\left(\mathrm{kg} / \mathrm{m}^{3}\right)$ & $\mu(\mathrm{MPa})$ & $\mathrm{V}_{\mathrm{s}}^{2}\left(\mathrm{~m}^{2} / \mathrm{s}^{2}\right)$ & $\begin{array}{l}\left\{4 / 3\left(\mathrm{~V}_{\mathrm{s}}^{2}\right)\right\} \\
\left(\mathrm{m}^{2} / \mathrm{s}^{2}\right)\end{array}$ & $\begin{array}{l}\left\{\left(\mathrm{V}_{\mathrm{p}}^{2}\right)-4 / 3\left(\mathrm{~V}_{\mathrm{s}}^{2}\right)\right\} \\
\left(\mathrm{m}^{2} / \mathrm{s}^{2}\right)\end{array}$ & $\mathrm{K}(\mathrm{GPa})$ \\
\hline 1 & 76.706 & 1375.144 & 1.74621 & 1746.21 & 7.40361891022 & 5883.925 & 7845.233 & 1883177 & 3.2884 \\
2 & 76.742 & 1375.184 & 1.74621 & 1746.21 & 7.37781891131 & 5889.403 & 7852.537 & 1883279 & 3.2886 \\
3 & 76.837 & 1375.290 & 1.74621 & 1746.21 & 7.40381891422 & 5904.046 & 7872.062 & 1883550 & 3.2890 \\
4 & 76.979 & 1375.448 & 1.74621 & 1746.21 & 7.42941891856 & 5925.884 & 7901.179 & 1883955 & 3.2897 \\
5 & 77.136 & 1375.621 & 1.74621 & 1746.21 & 7.43891892334 & 5950.017 & 7933.356 & 1884401 & 3.2905 \\
6 & 77.273 & 1375.774 & 1.74621 & 1746.21 & 7.43071892753 & 5971.194 & 7961.592 & 1884791 & 3.2912 \\
7 & 77.366 & 1375.877 & 1.74621 & 1746.21 & 7.40541893037 & 5985.564 & 7980.751 & 1885056 & 3.2917 \\
8 & 77.404 & 1375.919 & 1.74621 & 1746.21 & 7.36851893153 & 5991.436 & 7988.581 & 1885164 & 3.2918 \\
9 & 77.389 & 1375.903 & 1.74621 & 1746.21 & 7.32601893109 & 5989.210 & 7985.614 & 1885123 & 3.2918 \\
10 & 77.336 & 1375.843 & 1.74621 & 1746.21 & 7.28131892944 & 5980.862 & 7974.482 & 1884969 & 3.2915 \\
11 & 77.261 & 1375.760 & 1.74621 & 1746.21 & 7.23891892716 & 5969.322 & 7959.096 & 1884757 & 3.2911 \\
12 & 77.187 & 1375.678 & 1.74621 & 1746.21 & 7.20291892491 & 5957.929 & 7943.906 & 1884547 & 3.2908 \\
13 & 77.136 & 1375.621 & 1.74621 & 1746.21 & 7.17381892334 & 5950.041 & 7933.388 & 1884401 & 3.2905 \\
14 & 77.129 & 1375.613 & 1.74621 & 1746.21 & 7.15381892312 & 5948.885 & 7931.846 & 1884380 & 3.2905 \\
15 & 77.481 & 1376.005 & 1.74621 & 1746.21 & 7.47031893389 & 6003.432 & 8004.576 & 1885385 & 3.2922 \\
\hline
\end{tabular}

Table 3:NEHRP Seismic Site Classification Based on Shear-Wave Velocity $\left(\mathrm{V}_{\mathrm{s}}\right)$ Ranges.

\begin{tabular}{|c|c|c|}
\hline Site Class & S-Wave Velocity $\left(\mathrm{V}_{\mathrm{s}}\right)(\mathrm{ft} / \mathrm{s})$ & S-Wave Velocity $\left(\mathrm{V}_{\mathrm{s}}\right)(\mathrm{m} / \mathrm{s})$ \\
\hline $\begin{array}{l}\text { A } \\
\text { (Hard rock) }\end{array}$ & $>5000$ & $>1500$ \\
\hline (Rock) & $2500-5000$ & $760-1500$ \\
\hline $\begin{array}{l}\text { C } \\
\text { (Very dense soil and soft rock) }\end{array}$ & $1200-2500$ & $360-760$ \\
\hline $\begin{array}{l}\text { D } \\
\text { (Stiff Soil) }\end{array}$ & $600-1200$ & $180-360$ \\
\hline $\begin{array}{l}\text { E } \\
\text { (Soft Clay Soil) }\end{array}$ & $<600$ & $<180$ \\
\hline $\begin{array}{l}\text { F } \\
\text { (Soils requiring additional response) }\end{array}$ & $<600$ and meeting some additional conditions & $<180$ and meeting some requirements \\
\hline
\end{tabular}

\section{Conclusions}

In this study, a geophysical investigation of the competence of subsurface layers in the area around a proposed new power plant site in Edo State has been carried out. The results from the geophysical survey conducted to investigate the strength of these layers reveal that these sites have relatively low bulk moduli in the range of 3-4 GPa, while the shear modulus $(\mu)$ values range from 7.15-7.43 MPa These values are indicative of low to moderate strength for the subsurface strata underlying the area. The shearwave velocities obtainable from this survey depicts that of soft clay soil.

Although the degree of competence is low, the clayey sand and sandy clay layers can be grouted (ground improvement technique) by pumping cement at very high pressures into the formations thereby making the site suitable for the installation of the power plant. Also a pile foundation (and in this case a frictional pile) can be used to anchor the plant to the competent rock.
Arising from the results and conclusions of this study, it should be noted that the method used for this survey is by no means exhaustive. The Microtremor Array Measurement (MAM) technique can also be used alongside the MASW to have a better control of depth to competent soil or rock.

\section{References}

[1] Adewumi, I. and Olorunfemi, M.O. (2005). Using Geoinformatics in Construction Management. Journal of Applied Sciences, 5(4), pp. 761-767. http://dx.doi.org/10.3923/jas.2005.761.767.

[2] Adesida, A.A., Reijers, T.J.A., Nwajide, C.S. (1997). Sequence Stratigraphic framework of the Niger Delta. Paper presented at the AAPG International Conference and Exhibition, Vienna, Austria.

[3] Aina, A., Olorunfemi, M.O. and Ojo, J.S. (1996). An Integration of Aeromagnetic and Electrical Resistivity Methods in Dam Site Investigation. Geophysics, 61(2), pp. 349-356. http://dx.doi.org/10.1190/1.1443963. 
[4] Aki, K. (1957). Space and Time-Spectra of Stationary Stochastic Waves, with special reference to Microtremors. Bulletin of the Earth quake Research Institute: Tokyo University, 25, pp. 415-457.

[5] Aki, K. (1965). A note on the use of Microseisms in determining the Shallow Structures of the Earth's crust. Geophysics, 30(4), pp. 665 666. http://dx.doi.org/10.1190/1.1439640.

[6] Baker, R.D. (1997). Electrical Imaging and its applications in Engineering Investigation. In: McCann, D.M., Eddleston, M., Fenning, P.J., and Reeves, G.M (Eds.). Modern Geophysics in Engineering Geology. Geological Society Engineering Geology Special Publication, 12, pp. 37-43.

[7] Dorman, J. and Ewing, M. (1962). Numerical Inversion of Seismic Surface Wave Dispersion Data and Crust-Mantle Structure in the New York-Pennsylvania area. Journal of Geophysical Research, 67(13), pp 5227-5241.http://dx.doi.org/10.1029/JZ067i013p05227.

[8] Doust, H. and Omatsola, E. (1989). Niger Delta. AAPG Memoir, 48, pp. 201-238

[9] Dutta, N.P. (1984). Seismic Refraction Method to study the Foundation Rock of a Dam. Geophysical Prospecting, 32, pp. 1103 1110.http://dx.doi.org/10.1111/j.1365-2478.1984.tb00757.x.

[10]Ejewade, J.E. (1989). The Eastern Niger Delta: Geological Evolution and Hydrocarbon Occurences. SPDC Internal Report, Exploration Note 89 , pp. 002

[11]Evamy, B.D., Harembourne, J., Kameling, P., Knaap, W.A., Molloy, F.A., Rowlands, P.H. (1978). Hydrocarbon Habitat of Tertiary Niger Delta. AAPG Bulletin, 62, pp. 1-39.

[12]Gucunski, N. and Woods, R.D. (1991). Instrumentation for SASW testing, in Bhatia, S.K., and Blaney, G.W., Eds., Recent Advances in Instrumentation, Data Acquisition and Testing in Soil Dynamics: Am. Soc. Civil Eng., 1-16.

[13]Haney, M.M. and Miller, R. (2013). Introduction: Nonreflection Seismic and Inversion of Surface and Guided Waves. The Leading Edge, 32(6), pp. 610-611. http://dx.doi.org/10.1190/tle32060610.1.

[14]Hole, J.A., Zelt, C.A. and Pratt, R.G. (2005). Advances in ControlledSource Seismic Imaging: Eos Transactions. American Geophysical Union, 86, pp. 177 and 181. http://dx.doi.org/10.1029/2005EO180001.

[15]Idornigie, A.I., Olorunfemi, M.O. and Omitogun, A.A. (2006). Integration of Remotely Sensed and Geophysical Data Sets in Engineering Site Characterization in a Basement Complex area of Southwestern Nigeria. Journal of Applied Sciences Research, 2(9), pp. 541-552.

[16]Jones, H.A. and Hockey, R.D. (1964). The Geology of Part of Southwestern Nigeria. Geol. Surv. Nigeria Bull, 31(87).

[17]Knox, G. and Omatsola, M.E. (1989). Development of the Cenozoic Niger Delta in terms of the Escalator Regression Model. Proceedings, Coastal Lowlands and Geomorphology, Kon. Nederl. Geol. Mijnb. Genootschap, pp. 181-202. http://dx.doi.org/10.1007/978-94-017$\underline{1064-0 \quad 12}$

[18]Lin, F.C., Schmandt, B. and Tsai, V.C. (2012). Joint Inversion of Rayleigh Wave Phase Velocity and Ellipticity using USArray: Constraining Velocity and Density Structure in the Upper Crust. Geophysical Research Letters, 39(12), L12303. http://dx.doi.org/10.1029/2012GL052196.

[19]Louie, J.N. (2001). Faster, Better: Shear-Wave Velocity to 100 meter Depth from Refraction Microtremor Arrays. Bulletin of the Seismological Society of America, 91(2), pp. 347-364. http://dx.doi.org/10.1785/0120000098.

[20] Miller, R.D., Xia, J.C., Park, B. and Ivanov, J. (1999). Multichannel Analysis of Surface Waves to Map Bedrock: The Leading Edge, 18(12), pp. 1392-1396, http://dx.doi.org/10.1190/1.1438226.

[21]Nazarian, S. (1984). In situ Determination of Elastic Moduli of Soil Deposits and Pavement Systems by Spectral-Analysis-of-SurfaceWaves Method: Ph.D. Dissertation, Univ. of Texas, Austin.

[22]Nazarian, S., Stokoe, K.H., II and Hudson,W.R. (1983). Use of Spectral Analysis of Surface Waves Method for Determination of Modul and Thicknesses of Pavement Systems: Transport. Res. Record, 930 pp. 38-45.

[23] Obaje, N.G. (2009). Lecture Notes in Earth Sciences: Geology and Mineral Resources of Nigeria. Springer, New York. pp. 14, 109113.http://dx.doi.org/10.1007/978-3-540-92685-6.

[24]Okada, H. (2003). The Microtremor Survey Method: SEG, http://dx.doi.org/10.1190/1.9781560801740.

[25] Okosun, E.A. (1988). Review of the Early Tertiary Stratigraphy of Southwestern Nigeria. Journal of Mining and Geology, 34, 27-35.

[26]Olorunfemi, M.O. (2008). Voyage on the Skin of the Earth: A Geophysical Experience. Inaugural Lecture 211, Obafemi Awolowo University, Ile-Ife, Nigeria. $75 \mathrm{pp}$.
[27] Olorunfemi, M.O. and Meshida, E.A. (1987). Engineering Geophysics and its application in Engineering Site Investigations: A Case Study from Ile-Ife Area. The Nigerian Engineer, 22(2), pp. 57-66.

[28] Omosuyi, G.O. (2008). Geoelectric Sounding to Delineate Shallow Aquifers in the Coastal Plain Sands of Okitipupa Area, Southwestern Nigeria. The Pacific Journal of Science and Technology, 9(2), pp. 562-577.

[29]Pan, Y., Xia, J. and Zeng, C. (2013). Verification of Correctness of using Real Part of Complex Root as Rayleigh Wave Phase Velocity by Synthetic Data: Journal of Applied Geophysics, 88, pp. 94-100. http://dx.doi.org/10.1016/j.jappgeo.2012.09.012.

[30]Park, C.B., Xia, J. and Miller, R.D. (1998a). Ground Roll as a Tool to Image Near-Surface Anomaly: 68th Ann. Internat. Mtg., Soc. Expl. Geophys., Expanded Abstracts, pp. 874-877.

[31]Park, C.B., Xia, J. and Miller, R.D. (1998b). Imaging Dispersion Curves of Surface Waves on Multi-Channel Record: 68th Ann. Internat. Mtg., Soc. Expl. Geophys., Expanded Abstracts, pp. 1377-1380.

[32]Rix, G.J. and Leipski, E.A. (1991). Accuracy and Resolution of Surface Wave Inversion, in Bhatia, S.K. and Blaney, G.W., Eds., Recent Advances in Instrumentation, Data Acquisition and Testing in Soil Dynamics: Am. Soc. Civil Eng., pp.17-32.

[33]Sangodiji, E.E. and Olorunfemi, M.O. (2013). Geophysical Investigation of a Suspected Foundation Failure at Ogbomoso, Southwestern, Nigeria. The Pacific Journal of Science and Technology, 14(2), pp. 522-536.

[34] SeisImager/SWTM Manual (Windows Software for Analysis of Surface Waves) version 3.0 (2009). Geometrics, Inc.

[35] Song, Y.Y., Castagna, J.P., Black, R.A. and Knapp, R.W. (1989). Sensitivity of Near-Surface Shear-Wave Velocity Determination from Rayleigh and Love waves: 59th Annual International Meeting, SEG, Expanded Abstracts, pp. 509-512. http://dx.doi.org/10.1190/1.1889669.

[36] Sjqgren, B., фfsthus, A. and Sandberg, J. (1979). Seismic Classification of Rock Mass Qualities. Geophysical Prospecting, 27(2), pp. 409442.http://dx.doi.org/10.1111/j.1365-2478.1979.tb00977.x.

[37] Stokoe, K.H., II, Wright, G.W., James, A.B. and Jose, M.R. (1994). Characterization of Geotechnical sites by SASW Method, in Woods, R.D., Ed., Geophysical Characterization of Sites: Oxford Publ.

[38]Xia, J., Miller R.D. and Park C.B. (1999). Estimation of Near-Surface Shear-Wave Velocity by Inversion of Rayleigh waves: Geophysics, 64(3), pp. 691-700.http://dx.doi.org/10.1190/1.1444578.

[39]Weber, K.J. (1972). Sedimentological Aspects of Oil Fields in the Niger-Delta. GeologeenMijnbouw. 50, pp. 559-576

[40] Yilmaz, O. (1987). Seismic Data Processing: Soc. of Expl. Geophys.

[41] Yilmaz, O., Eser, M. and Berilgen, M. (2009). Applications of Engineering Seismology for Site Characterization: Journal of Earth Science, 20(3), pp. 546-554.http://dx.doi.org/10.1007/s12583-009-0045-9. 